\title{
Nocardioides marinus sp. nov.
}

Correspondence

Byung Cheol Cho

bccho@snu.ac.kr

\section{Dong Han Choi, ${ }^{1}$ Hye Min Kim, ${ }^{2}$ Jae-Hoon Noh ${ }^{1}$ and Byung Cheol $\mathrm{Cho}^{2}$}

\author{
${ }^{1}$ Marine Environmental Research Department, Korea Ocean Research and Development \\ Institute, Ansan 426-744, Republic of Korea \\ ${ }^{2}$ School of Earth and Environmental Sciences, Seoul National University, Shillim-dong, \\ Kwanak-gu, Seoul 151-742, Republic of Korea
}

Since the original description of the genus Nocardioides (Prauser, 1976), many species of the genus have been isolated from various environments including soil, herbage, groundwater, an oil-shale column, black sand, crude oil, a saline lake and a tidal flat (Yoon et al., 2006a, b, 2007; Lee, 2007). Most of these species were isolated from non-saline environments, although species such as Nocardioides aquaticus (Lawson et al., 2000), Nocardioides aestuarii (Yi \& Chun, 2004b) and Nocardioides ganghwensis (Yi \& Chun, 2004a) were isolated from marine environments. In the present study, a strain affiliated with the genus Nocardioides was isolated from seawater and subjected to a polyphasic taxonomic analysis.

Strain CL-DD14 ${ }^{\mathrm{T}}$ was isolated from seawater around 'Dokdo' island in the East Sea, Korea, using a selective $\mathrm{S}$ medium ( $10 \mathrm{~g}$ $\mathrm{Na}_{2} \mathrm{HPO}_{4}, 3 \mathrm{~g} \mathrm{KH}_{2} \mathrm{PO}_{4}, 1 \mathrm{~g} \mathrm{~K} \mathrm{~K}_{2} \mathrm{SO}_{4}, 30 \mathrm{~g} \mathrm{NaCl}, 0.2 \mathrm{~g}$ $\mathrm{MgSO}_{4} .7 \mathrm{H}_{2} \mathrm{O}, 0.01 \mathrm{~g} \mathrm{CaCl}, 0.001 \mathrm{~g} \quad \mathrm{FeSO}_{4} .7 \mathrm{H}_{2} \mathrm{O}, 1 \mathrm{~g}$ Casamino acids, $1 \mathrm{~g}$ yeast extract, $20 \mathrm{~g}$ glucose and $20 \mathrm{~g}$ Bacto agar, per litre distilled water; Fialho et al., 1999). Subsequently, the isolate was routinely cultivated on marine agar 2216 (MA; Difco) at $30^{\circ} \mathrm{C}$ and maintained both on MA at $4{ }^{\circ} \mathrm{C}$ and in marine broth (MB; Difco) supplemented with $30 \%(\mathrm{v} / \mathrm{v})$ glycerol at $-80^{\circ} \mathrm{C}$.

The GenBank/EMBL/DDBJ accession number for the 16S rRNA gene sequence of strain CL-DD14 ${ }^{\top}$ is DQ401093.

A table detailing the cellular fatty acid content of strain $C L-D D 14^{\top}$ and other species of the genus Nocardioides is available as supplementary material in IJSEM Online.
Morphological, physiological and biochemical analyses were performed with MA as the basal medium at $30^{\circ} \mathrm{C}$. Gram staining was performed as described by Smibert \& Krieg (1994). Cell morphology and motility were observed by phase-contrast microscopy. Transmission electron microscopy subsequent to negative staining was used to establish whether flagella were present. Anaerobic growth on MA was checked by using the GasPack anaerobic system (BBL). Catalase and oxidase activities and degradation of casein, hypoxanthine, xanthine and L-tyrosine were determined according to the protocols described by Smibert \& Krieg (1994). Degradation of Tween 80 was examined as described by Hansen \& Sørheim (1991).

The temperature range for growth was determined on the basis of formation of visible single colonies on MA incubated at $5-45^{\circ} \mathrm{C}$, at intervals of $5{ }^{\circ} \mathrm{C}$ for 1 month. The $\mathrm{pH}$ range (between $\mathrm{pH} 5$ and 10 at intervals of one $\mathrm{pH}$ unit) for growth was determined by changes in $\mathrm{OD}_{600}$ with time in $\mathrm{MB}$. The final $\mathrm{pH}$ was adjusted using $1 \mathrm{M} \mathrm{NaOH}$ and $1 \mathrm{~N} \mathrm{HCl}$ solutions. Tolerance of strain CL-DD14 ${ }^{\mathrm{T}}$ to $\mathrm{NaCl}$ was determined by using synthetic ZoBell broth $(5 \mathrm{~g}$ Bacto peptone, $1 \mathrm{~g}$ yeast extract, $0.1 \mathrm{~g}$ ferric citrate, per litre distilled water) with various concentrations $(0,0.5,1,2,3,4,5$, $6,7,8,9,10,15,20 \%, \mathrm{w} / \mathrm{v})$ of $\mathrm{NaCl}$. Nitrate reduction, production of indole, arginine dihydrolase, urease, gelatinase and $\beta$-galactosidase activities, acid production from glucose, and hydrolysis of aesculin were tested by using the API 20NE kit (bioMérieux) according to the manufacturer's instructions, except that cell suspension was prepared using 
Table 1. Characteristics differentiating strain CL-DD14 ${ }^{\top}$ from related species of the genus Nocardioides

Taxa: 1, strain CL-DD14 $4^{\mathrm{T}} ; 2$, N. aquiterrae; 3, N. pyridinolyticus; 4, N. albus; 5, N. luteus; 6, N. kribbensis; 7, N. aquaticus; 8, N. aestuarii; 9, N. ganghwensis. Data are from Yoon et al. $(1997,2004,2005,2006 \mathrm{a})$, Lawson et al. (2000) and Yi \& Chun $(2004 \mathrm{a}, \mathrm{b})$. +, Positive; - , negative; W, weakly positive; V, variable; ND, not determined. Strain CL-DD14 ${ }^{\mathrm{T}}$ was positive for $\alpha$-glucosidase, esterase lipase (C8) and leucine arylamidase, but negative for $\beta$-galactosidase, $\beta$-glucosidase, $\beta$-glucuronidase, $N$-acetyl- $\beta$-glucosaminidase, $\alpha$-fucosidase and lipase (C14) according to API ZYM tests. Strain CL-DD14 ${ }^{\mathrm{T}}$ also utilized D-glucose, D-mannitol, D-trehalose and sucrose, but not acetamide, L-arginine or tartrate.

\begin{tabular}{|c|c|c|c|c|c|c|c|c|c|}
\hline Characteristic & 1 & 2 & 3 & 4 & 5 & 6 & 7 & 8 & 9 \\
\hline Cell morphology & Rods, cocci & Rods, cocci & Rods, cocci & Hyphae & Hyphae & Short rods, cocci & Cocci, short rods & Rods & Rods \\
\hline Motility & - & + & + & - & - & - & - & - & - \\
\hline Temperature range $\left({ }^{\circ} \mathrm{C}\right)$ (optimum) & $10-40(25-30)$ & $15-42(30)$ & $20-40(35)$ & $(28)$ & (28) & $4-35(30)$ & $(16-26)$ & 20-35 (30) & $10-40(30)$ \\
\hline $\mathrm{NaCl}$ tolerance range (\%) (optimum) & $0.5-8(1-3)$ & ND & $\mathrm{ND}$ & $\mathrm{ND}$ & $\mathrm{ND}$ & $0-3$ & $\mathrm{ND}$ & $0-8(0-2)$ & $0-8(0-1)$ \\
\hline $\mathrm{pH}$ range (optimum) & $6-9(7-8)$ & $(6-7)$ & $5-9(8)$ & ND & ND & $6-11(9)$ & ND & $6-10(7)$ & $6-10(7)$ \\
\hline Oxidase & - & + & - & - & - & + & - & - & - \\
\hline Nitrate reduction & - & + & + & - & - & + & + & - & + \\
\hline Gelatinase & - & + & + & + & + & + & + & + & + \\
\hline \multicolumn{10}{|l|}{ Decomposition of: } \\
\hline Starch & - & $-{ }^{\star}$ & + & + & + & - & $\mathrm{W}^{*}$ & - & + \\
\hline Tween 80 & + & + & - & + & + & + & + & + & + \\
\hline Tyrosine & - & - & + & + & + & + & + & - & + \\
\hline Hypoxanthine & - & - & - & + & + & - & - & - & - \\
\hline Xanthine & - & $-{ }^{\star}$ & + & + & $-^{\star}$ & - & - & - & $\mathrm{W}$ \\
\hline \multicolumn{10}{|l|}{ API ZYM test results: } \\
\hline Alkaline phosphatase & + & - & + & + & $\mathrm{V}$ & + & $\mathrm{V}$ & $\mathrm{W}$ & + \\
\hline Esterase $(\mathrm{C} 4)$ & $\mathrm{W}$ & - & - & + & + & + & $\mathrm{W}$ & + & $\mathrm{V}$ \\
\hline Valine arylamidase & W & - & $\mathrm{W}$ & - & - & - & W & + & + \\
\hline Cystine arylamidase & - & $\mathrm{W}$ & - & - & - & - & $\mathrm{V}$ & - & $\mathrm{W}$ \\
\hline Trypsin & + & + & + & + & + & - & $\mathrm{W}$ & + & - \\
\hline$\alpha$-Chymotrypsin & - & - & - & - & - & + & - & + & - \\
\hline Acid phosphatase & $\mathrm{W}$ & + & + & - & - & + & + & $\mathrm{W}$ & $\mathrm{W}$ \\
\hline Naphthol-AS-BI-phosphohydrolase & - & + & + & $\mathrm{W}$ & $\mathrm{V}$ & + & - & $\mathrm{W}$ & - \\
\hline$\alpha$-Galactosidase & - & - & - & - & - & - & - & - & + \\
\hline$\alpha$-Mannosidase & - & - & - & - & + & - & - & - & - \\
\hline \multicolumn{10}{|l|}{ Carbon utilization: } \\
\hline Benzoate & - & - & - & + & + & ND & - & - & - \\
\hline Citrate & - & $\mathrm{W}$ & - & + & + & $\mathrm{ND}$ & - & + & + \\
\hline D-Fructose & + & + & + & + & $-{ }^{\star}$ & - & + & + & + \\
\hline D-Galactose & + & + & + & + & - & + & $-^{*}$ & + & + \\
\hline D-Mannose & - & $+^{*}$ & $+^{*}$ & + & + & - & - & - & + \\
\hline D-Raffinose & - & - & - & V & - & + & - & $\mathrm{w}$ & + \\
\hline D-Ribose & - & $\mathrm{W}^{\star}$ & + & - & - & + & - & - & - \\
\hline D-Xylose & + & + & + & + & + & - & $\mathrm{W}^{\star}$ & + & + \\
\hline
\end{tabular}




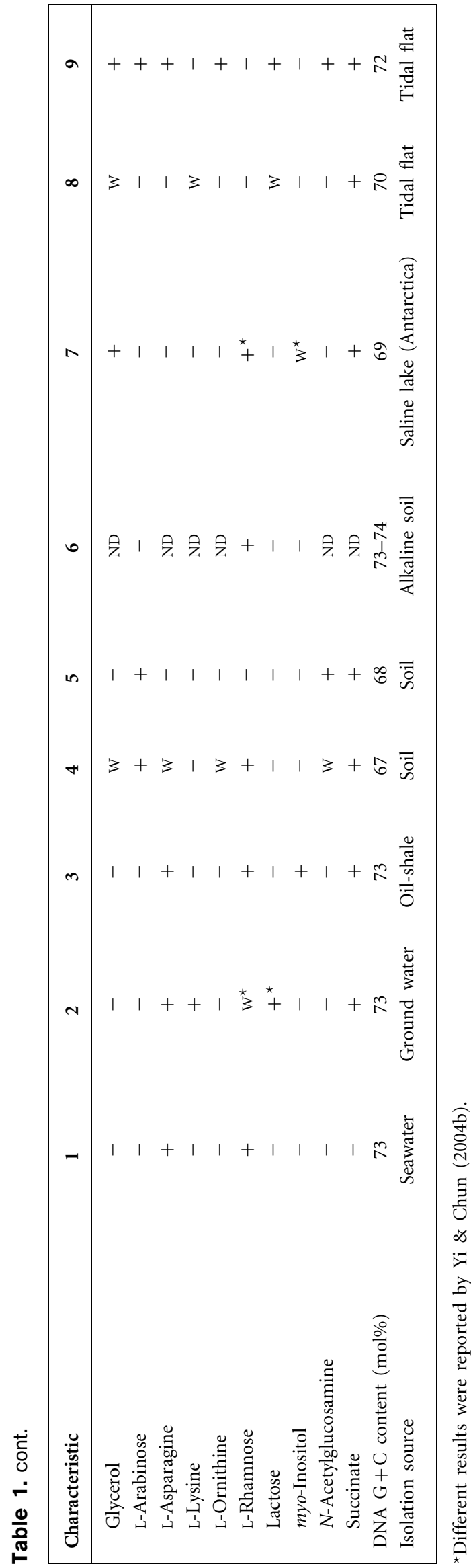

half-strength artificial seawater (ASW; $24 \mathrm{~g} \mathrm{NaCl}, 5.1 \mathrm{~g}$ $\mathrm{MgCl}_{2}, 4 \mathrm{~g} \mathrm{Na}_{2} \mathrm{SO}_{4}, 1.1 \mathrm{~g} \mathrm{CaCl}_{2}, 0.7 \mathrm{~g} \mathrm{KCl}, 0.2 \mathrm{~g} \mathrm{NaHCO}_{3}$, $0.1 \mathrm{~g} \mathrm{KBr}, 0.027 \mathrm{~g} \mathrm{H}_{3} \mathrm{BO}_{3}, 0.024 \mathrm{~g} \mathrm{SrCl}_{2}, 0.003 \mathrm{~g} \mathrm{NaF}$, per litre distilled water; Lyman \& Fleming, 1940) as the suspension medium. Other enzymic activities were determined with the API ZYM kit (bioMérieux) and half-strength ASW as the suspension medium. Carbon utilization was tested by using a modified basal medium $(11.8 \mathrm{~g} \mathrm{NaCl}$, $0.32 \mathrm{~g} \mathrm{KCl}, 2.26 \mathrm{~g} \mathrm{MgCl}_{2} .6 \mathrm{H}_{2} \mathrm{O}, 2.97 \mathrm{~g} \mathrm{MgSO}_{4} .7 \mathrm{H}_{2} \mathrm{O}$, $0.65 \mathrm{~g} \mathrm{CaCl}_{2} .2 \mathrm{H}_{2} \mathrm{O}, 0.2 \mathrm{~g} \mathrm{NaNO}_{3}, 0.2 \mathrm{~g} \mathrm{NH}_{4} \mathrm{Cl}$, per litre distilled water) supplemented with yeast extract $\left(0.05 \mathrm{~g} \mathrm{l}^{-1}\right)$ based on changes in $\mathrm{OD}_{600}$ with time for 1 month. Concentrations of added carbon source were $0.2 \%$ (final concentration). A test tube without any carbon source was used as a negative control. The results of morphological, physiological and biochemical tests are given in Table 1 and in the species description below.

Isoprenoid quinones were isolated according to the method of Minnikin et al. (1984) and analysed by HPLC as described by Collins (1985) at the Korean Culture Center of Microorganisms (KCCM, Seoul, Republic of Korea). Cell-wall diamino acids were determined as described by Staneck \& Roberts (1974). The whole-cell fatty acid methyl esters of strain CL-DD14 $4^{\mathrm{T}}$, grown on MA plates at $30^{\circ} \mathrm{C}$ for 1 day, were analysed by GC according to the instructions of the Microbial Identification System (MIDI) at KCCM. Strain CL-DD $14^{\mathrm{T}}$ contained tetrahydrogenated menaquinone with eight isoprene units [MK-8 $\left.\left(\mathrm{H}_{4}\right)\right]$ as the major menaquinone and LL-diaminopimelic acid as the cell-wall diamino acid. The cellular fatty acid composition of strain CL-DD $14^{\mathrm{T}}$ was as follows: branched fatty acids iso- $\mathrm{C}_{16: 0}(71.5 \%)$, iso- $\mathrm{C}_{18: 0}$ $(2.1 \%)$ and iso- $\mathrm{C}_{14: 0}(2.0 \%)$; 10-methyl fatty acids $\mathrm{C}_{17: 0}$ (5.1\%), $\mathrm{C}_{18: 0}(1.7 \%)$ and $\mathrm{C}_{16: 0}(1.4 \%)$; unsaturated fatty acids $\mathrm{C}_{18: 1} \omega 9 c(4.4 \%), \mathrm{C}_{17: 1} \omega 8 c(3.8 \%)$ and $\mathrm{C}_{18: 1} \omega 7 c$ $(1.6 \%)$; saturated fatty acid $\mathrm{C}_{16: 0}(1.3 \%)$, and summed feature 3, comprising iso- $\mathrm{C}_{15: 0} 2-\mathrm{OH}$ and/or $\mathrm{C}_{16: 1} \omega 7 c$, $(1.3 \%)$ (see Supplementary Table S1 available in IJSEM Online). Predominant fatty acids were iso- $\mathrm{C}_{16: 0}$ and the

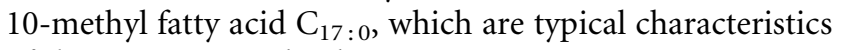
of the genus Nocardioides.

The 16S rRNA gene was amplified by PCR with Taq DNA polymerase (Bioneer) and primers $27 \mathrm{~F}$ and $1492 \mathrm{R}$ (Lane, 1991). The PCR product was purified by using the AccuPrep PCR purification kit (Bioneer) and cloned by using the pGEM Easy TA vector (Promega). Sequencing of the $16 \mathrm{~S}$ rRNA gene was performed with an Applied Biosystems automatic sequencer (ABI3730XL) at Macrogen Corp., Seoul, Republic of Korea. The almost-complete 16S rRNA gene sequence of strain CL-DD14 ${ }^{\mathrm{T}}(1440 \mathrm{bp})$ was obtained. The sequence was compared with those available in GenBank using BLASTN searches (Altschul et al., 1990). The 16S rRNA gene sequence of strain CL-DD14 ${ }^{\mathrm{T}}$ was manually aligned with those of the type strains of other species belonging to the genus Nocardioides and phylogenetically related genera obtained from GenBank by using known 16S rRNA gene secondary structure information. 
Phylogenetic trees were obtained by the neighbour-joining (Saitou \& Nei, 1987), maximum-parsimony (Fitch, 1971) and maximum-likelihood (Felsenstein, 1981) methods. An evolutionary distance matrix for the neighbour-joining method was generated according to the model of Jukes \& Cantor (1969). The robustness of tree topologies was assessed by bootstrap analyses based on 1000 replications for the neighbour-joining and maximum-parsimony methods and 100 replications for the maximum-likelihood method. Alignment was carried out via the jPHYDIT program (Jeon et al., 2005) and phylogenetic analyses were performed with MEGA 3 (Kumar et al., 2004) and PAUP 4.0 (Swofford, 1998). Likelihood parameters were estimated by using the hierarchical ratio tests in MODELTEST version 3.04 (Posada \& Crandall, 1998). The DNA G $+\mathrm{C}$ content was determined by HPLC analysis (Tamaoka \& Komagata, 1984) at KCCM.

The DNA G+C content of strain CL-DD14 ${ }^{\mathrm{T}}$ was $72.9 \mathrm{~mol} \%$. 16S rRNA gene sequence analysis indicated that the closest relatives of strain CL-DD14 ${ }^{\mathrm{T}}$ were the type strains of Nocardioides aquiterrae ( $97.1 \%$ similarity), Nocardioides pyridinolyticus (96.6\%) and N. aestuarii (96.4\%). Other members of the genus Nocardioides showed 16S rRNA gene sequence similarities of $94.1-96.3 \%$ to the novel strain. Phylogenetic analyses based on 16S rRNA gene sequences indicated that strain CL-DD $14^{\mathrm{T}}$ formed an evolutionary lineage within the radiation enclosing most species of the genus Nocardioides. Similarity between strain CL-DD14 ${ }^{\mathrm{T}}$ and $N$. aquiterrae was close to the recommended guideline $(97 \%)$ for species designation at the $16 \mathrm{~S}$ rRNA gene level (Stackebrandt \& Goebel, 1994). However, a dendrogram of
$16 \mathrm{~S}$ rRNA gene sequence relationships showed that strain CL-DD14 ${ }^{\mathrm{T}}$ formed a distinct branch from N. aquiterrae and was recovered as a sister group to the subclade containing Nocardioides albus and Nocardioides luteus that exhibited low $16 \mathrm{~S}$ rRNA gene sequence similarity values (96.0-96.1\%) (Fig. 1). Furthermore, phenotypic features $(\mathrm{NaCl}$ requirement, temperature and $\mathrm{pH}$ ranges for growth, absence of motility, negative reactions for oxidase, gelatinase, nitrate reductase and naphthol-AS-BI-phosphohydrolase, presence of alkaline phosphatase, and carbon utilization pattern) clearly differentiated strain CL-DD14 ${ }^{\mathrm{T}}$ from $N$. aquiterrae (Table 1). In addition, strain CL-DD14 ${ }^{\mathrm{T}}$ could be differentiated from N. albus and N. luteus based on phenotypic characteristics (absence of hyphae, negative in tests for gelatin, tyrosine, hypoxanthine and starch hydrolysis, and carbon utilization patterns) (Table 1). In conclusion, phenotypic features and phylogenetic analyses based on $16 \mathrm{~S}$ rRNA gene sequences suggest that strain CL-DD14 ${ }^{\mathrm{T}}$ represents a novel species of the genus Nocardioides, for which the name Nocardioides marinus sp. nov. is proposed.

\section{Description of Nocardioides marinus sp. nov.}

Nocardioides marinus (ma.ri'nus. L. masc. adj. marinus referring to the sea, from where the type strain was isolated).

Cells are rods (about 1.0-1.8 $\mu \mathrm{m}$ long and 0.4-0.6 $\mu \mathrm{m}$ wide) in the exponential phase and coccus forms are found in the stationary phase. Cells are non-motile and strictly aerobic. Gram-positive, oxidase-negative and weakly catalase-positive. Colonies on MA are circular, smooth,

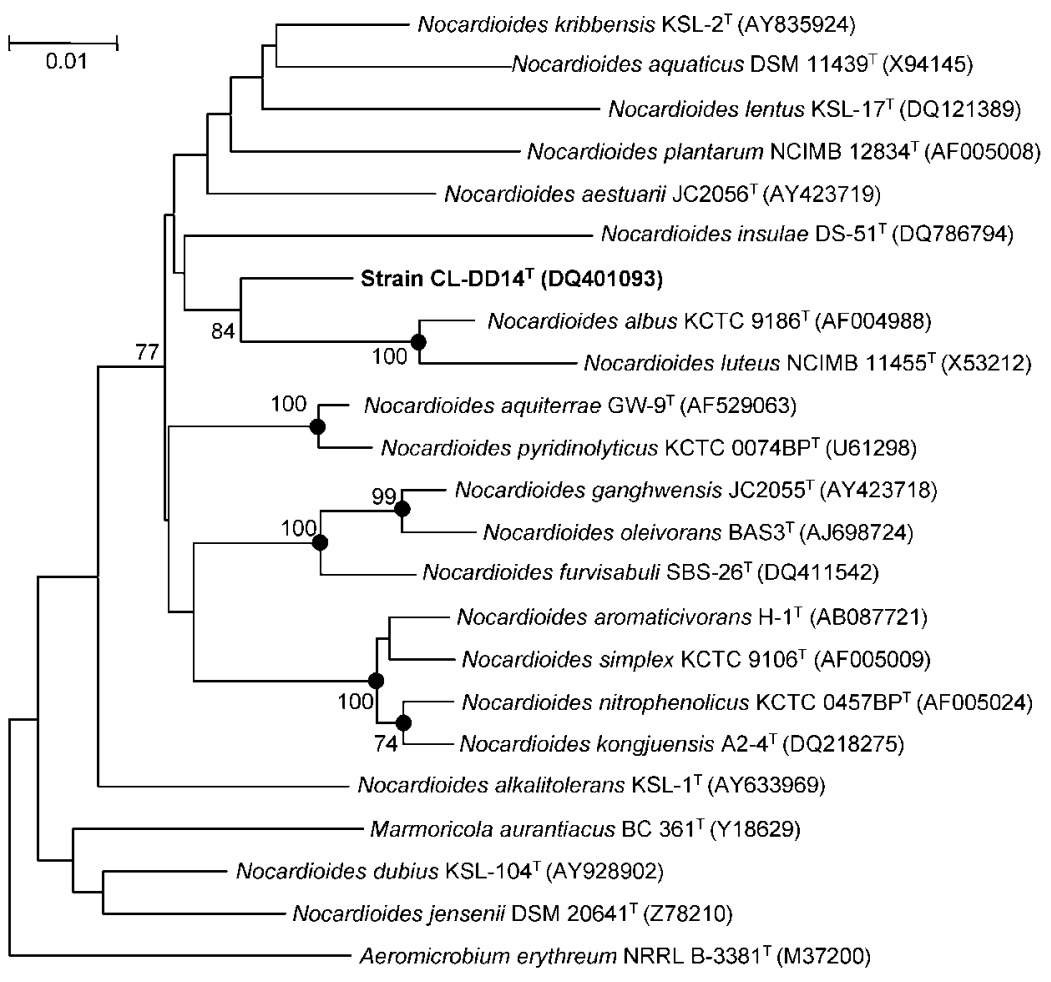

Fig. 1. Neighbour-joining tree based on 16S rRNA gene sequences showing the relationship between strain CL-DD14 ${ }^{\top}$ and members of the genus Nocardioides. Only bootstrap values (expressed as percentage of 1000 replications) greater than $70 \%$ are shown at nodes. Solid circles indicate that the corresponding nodes were also recovered in the maximum-likelihood and maximumparsimony trees. Terrabacter tumescens KCTC $9133^{\top}$ (AF005023) was used as an outgroup (not shown). Bar, 0.01 nucleotide substitutions per site. 
convex with an entire margin and creamy white. Substrate or aerial mycelium is not observed. Growth occurs at $10-40{ }^{\circ} \mathrm{C}$ (optimum about $25-30^{\circ} \mathrm{C}$ ) and at $\mathrm{pH}$ values of 6-9 (optimum $\mathrm{pH} 7-8$ ). Growth occurs at $\mathrm{NaCl}$ concentrations of $0.5-8 \%(\mathrm{w} / \mathrm{v})$ (optimum $1-3 \%)$. Negative in tests for nitrate reduction, indole production, glucose fermentation, arginine dihydrolase, urease and gelatinase, and positive for aesculin hydrolysis and $\beta$-galactosidase in API $20 \mathrm{NE}$ tests. Casein and Tween 80 are hydrolysed, but hypoxanthine, xanthine, L-tyrosine and starch are not. Major menaquinone is $\mathrm{MK}-8\left(\mathrm{H}_{4}\right)$. Cell-wall diamino acid is LLdiaminopimelic acid. The major fatty acids are iso- $\mathrm{C}_{16: 0}$ $(71.5 \%)$ and 10-methyl $\mathrm{C}_{17: 0}(5.1 \%)$. Results of API ZYM and carbon source utilization tests are given in Table 1 . The DNA G $+\mathrm{C}$ content is $72.9 \mathrm{~mol} \%$.

The type strain, CL-DD $14^{\mathrm{T}} \quad\left(=\mathrm{KCCM} \quad 42321^{\mathrm{T}}=\mathrm{DSM}\right.$ $18248^{\mathrm{T}}$ ), was isolated from seawater of the East Sea, Korea.

\section{Acknowledgements}

This work was supported in part by the EAST-I project (to B. C. C.), the BK21 project of the Korean Government and the POSEIDON project (No. PP06401 to J.-H. N.).

\section{References}

Altschul, S. F., Gish, W., Miller, W., Myers, E. W. \& Lipman, D. J. (1990). Basic local alignment search tool. J Mol Biol 215, 403-410.

Collins, M. D. (1985). Analysis of isoprenoid quinones. Methods Microbiol 18, 329-366.

Felsenstein, J. (1981). Evolutionary trees from DNA sequences: a maximum likelihood approach. J Mol Evol 17, 368-376.

Fialho, A. M., Martins, L. O., Donval, M. L., Leitao, J. H., Ridout, M. J., Jay, A. J., Morris, V. J. \& Sá-Correia, I. (1999). Structures and properties of gellan polymers produced by Sphingomonas paucimobilis ATCC 31461 from lactose compared with those produced from glucose and from cheese whey. Appl Environ Microbiol 65, 24852491.

Fitch, W. M. (1971). Toward defining the course of evolution: minimum change for a specific tree topology. Syst Zool 20, 406-416.

Hansen, G. H. \& Sørheim, R. (1991). Improved method for phenotypical characterization of marine bacteria. J Microbiol Methods 13, 231-241.

Jeon, Y. S., Chung, H., Park, S., Hur, I., Lee, J. H. \& Chun, J. (2005). jPHYDIT: a JAVA-based integrated environment for molecular phylogeny of ribosomal RNA sequences. Bioinformatics 21, 31713173.

Jukes, T. H. \& Cantor, C. R. (1969). Evolution of protein molecules. In Mammalian Protein Metabolism, pp. 21-132. Edited by H. N. Munro. New York: Academic Press.

Kumar, S., Tamura, K. \& Nei, M. (2004). MEGA 3: integrated software for molecular evolutionary genetics analysis and sequence alignment. Brief Bioinform 5, 150-163.

Lane, D. J. (1991). 16S/23S rRNA sequencing. In Nucleic Acid Techniques in Bacterial Systematics, pp. 115-175. Edited by E. Stackebrandt \& M. Goodfellow. Chichester: Wiley.
Lawson, P. A., Collins, M. D., Schumann, P., Tindall, B. J., Hirsch, P. \& Labrenz, M. (2000). New LL-diaminopimelic acid-containing actinomycetes from hypersaline, heliothermal and meromictic Antarctic Ekho Lake: Nocardioides aquaticus sp. nov. and Friedmanniella lacustris sp. nov. Syst Appl Microbiol 23, 219-229.

Lee, S. D. (2007). Nocardioides furvisabuli sp. nov., isolated from black sand. Int J Syst Evol Microbiol 57, 35-39.

Lyman, J. \& Fleming, R. H. (1940). Composition of sea water. J Mar Res 3, 134-146.

Minnikin, D. E., O'Donnell, A. G., Goodfellow, M., Alderson, G., Athalye, M., Schaal, K. \& Parlett, J. H. (1984). An integrated procedure for the extraction of bacterial isoprenoid quinines and polar lipids. J Microbiol Methods 2, 233-241.

Posada, D. \& Crandall, K. A. (1998). MODELTEST: testing the model of DNA substitution. Bioinformatics 14, 817-818.

Prauser, H. (1976). Nocardioides, a new genus of the order Actinomycetales. Int J Syst Bacteriol 26, 58-65.

Saitou, N. \& Nei, M. (1987). The neighbor-joining method: a new method for reconstructing phylogenetic trees. Mol Biol Evol 4, 406-425.

Smibert, R. M. \& Krieg, N. R. (1994). Phenotypic characterization. In Methods for General and Molecular Bacteriology, pp. 607-654. Edited by P. Gerhardt, R. G. E. Murray, W. A. Wood \& N. R. Krieg. Washington, DC: American Society for Microbiology.

Stackebrandt, E. \& Goebel, B. M. (1994). Taxonomic note: a place for DNA-DNA reassociation and 16S rRNA sequence analysis in the present species definition in bacteriology. Int J Syst Bacteriol 44, 846-849.

Staneck, J. L. \& Roberts, G. D. (1974). Simplified approach to the identification of aerobic actinomycetes by thin-layer chromatography. Appl Microbiol 28, 226-231.

Swofford, D. L. (1998). PAUP*: Phylogenetic analysis using parsimony, version 4. Sunderland, MA: Sinauer Associates.

Tamaoka, J. \& Komagata, K. (1984). Determination of DNA base composition by reversed-phase high-performance liquid chromatography. FEMS Microbiol Lett 25, 125-128.

Yi, H. \& Chun, J. (2004a). Nocardioides ganghwensis sp. nov., isolated from tidal flat sediment. Int J Syst Evol Microbiol 54, 1295-1299.

Yi, H. \& Chun, J. (2004b). Nocardioides aestuarii sp. nov., isolated from tidal flat sediment. Int J Syst Evol Microbiol 54, 2151-2154.

Yoon, J.-H., Rhee, S.-K., Lee, J.-S., Park, Y.-H. \& Lee, S. T. (1997). Nocardioides pyridinolyticus sp. nov., a pyridine-degrading bacterium isolated from the oxic zone of an oil shale column. Int J Syst Bacteriol 47, 933-938.

Yoon, J.-H., Kim, I.-G., Kang, K. H., Oh, T.-K. \& Park, Y.-H. (2004). Nocardioides aquiterrae sp. nov., isolated from groundwater in Korea. Int J Syst Evol Microbiol 54, 71-75.

Yoon, J.-H., Kim, I.-G., Lee, M.-H. \& Oh, T.-K. (2005). Nocardioides kribbensis sp. nov., isolated from an alkaline soil. Int J Syst Evol Microbiol 55, 1611-1614.

Yoon, J.-H., Lee, C.-H. \& Oh, T.-K. (2006a). Nocardioides lentus sp. nov., isolated from an alkaline soil. Int J Syst Evol Microbiol 56, 271-275.

Yoon, J.-H., Lee, J.-K., Jung, S.-Y., Kim, J.-A., Kim, H.-K. \& Oh, T.-K. (2006b). Nocardioides kongjuensis sp. nov., an $\mathrm{N}$-acylhomoserine lactone-degrading bacterium. Int J Syst Evol Microbiol 56, 1783-1787.

Yoon, J.-H., Kang, S.-J., Lee, C.-H. \& Oh, T.-K. (2007). Nocardioides insulae sp. nov., isolated from soil. Int J Syst Evol Microbiol 57, $136-140$. 